\title{
Determinants of Sterilization Birth Control Method in Bangladesh
}

\author{
Mohammad Nazmul Hoq, Mohammad Emdad Hossain, Israth Sultana \\ International Islamic University Chittagong, Bangladesh \\ Email: ronyfirst@yahoo.com
}

How to cite this paper: Hoq, M.N., Hossain, M.E. and Sultana, I. (2019) Determinants of Sterilization Birth Control Method in Bangladesh. Open Journal of Social Sciences, 7, 31-43. https://doi.org/10.4236/jss.2019.79003

Received: August 4, 2019

Accepted: August 29, 2019

Published: September 2, 2019

Copyright ( 2019 by author(s) and Scientific Research Publishing Inc. This work is licensed under the Creative Commons Attribution International License (CC BY 4.0).

http://creativecommons.org/licenses/by/4.0/

(c) (i) Open Access

\begin{abstract}
Sterilization is one of the best ways to deal with population growth in a country. As the fertility rate in Bangladesh is almost in the steady condition in the last decades, this article explores the continuing low preference of sterilization method rather than other birth control methods. For this purpose, the present study utilized 2014 Bangladesh Demographic and Health Survey data set (BDHS, 2014) ${ }^{1}$. The Cross-tabulation and Logistic Regression analyses were employed to identify the different demographic and socioeconomic factors which affect the decision of using a permanent contraceptive method. The study found that working status and social position of the respondents had a positive relation with choice of sterilization, but interestingly the study identified that education of couples had an unexpected negative correlation with the decision of sterilization. Moreover, the study found that the decision of sterilization strongly depends on the number of sons of the respondents.
\end{abstract}

\section{Keywords}

Sterilization, Socioeconomic Factors, Demographic Factors, Gender Preference, Bangladesh

\section{Introduction}

Family planning through contraceptive use is a primary segment of conceptive social insurance; it enables women and their families to have the wanted number of child's and furthermore to control the planning of pregnancies. The capacity to restrain and space pregnancies significantly affect a women's prosperity, child survival, and financial development and improvement.

The nations of South Asia have gained ground in expanding access to modern family planning method, and lessening complete fertility rates, and the region ${ }^{1}$ Data source: https://dhsprogram.com/data/dataset/Bangladesh_Standard-DHS_2014.cfm?flag=0. 
still records for the second most noteworthy weight of maternal death. Poor, minimized, and uneducated families don't approach the reproductive wellbeing services, but they need, including limitation of family size. Unintended pregnancies remain a notable problem in worldwide in the context of public health despite the extensive advances in preventative innovations. In this century, women have accessed numerous advanced family planning methods, while unmet need for contraception is still high in developing countries. Contraception and unmet need levels shifted and varied over nations of the world, the most minimal contraception and most astounding unmet need, being in sub-Saharan Africa primarily due to the low degree of learning and presence of different types of obstructions [1] [2]. A few nations in Asian countries have gained significant ground expanding the utilization of present-day contraceptives. However, significant disparities remain between and inside the countries. Picking a permanent method is influenced by the quantity of determinants, accessibility, availability, affordability, counting socio-social and fertility factors, life partner impact, and other statistic factors [3] [4].

In Bangladesh, there has been a move far from the present day, traditional methods to modern techniques. The family planning projects have been extraordinarily worried about the utilization adequacy of contraceptives as opposed to their health wellbeing. Diverse family planning techniques have distinctive viability, accommodation of utilization, accessibility or availability, just as reasonableness for an individual couple. Based on accommodation, women are well on the way to utilize the pill over other present-day strategies, while they are most drastically averse to use sterilization method [5]. Different population background qualities identified with wellbeing, population, and monetary approach conditions, family structure, and individual attributes were related to permanent contraception [6]. Previous investigations of preventative use and strategy decision at the individual level found solid regional and urban-rural variety in birth control method use and technique decision [7].

Family planning is a reasonable answer to control rapid growth of population in a country. Notwithstanding separating and restricting the quantity of child, which improves maternal and child wellbeing, engages women and upgrades financial advancement. Couples these days are settling their life on better approaches to characterize and design their family size and are abandoning old traditional contraceptive method. Family planning techniques reflect individual preference, social norms, and social standards, and local and provincial issues influencing birth control methods accessibility and openness, including policies and cost.

Female sterilization is the most widely recognized in developing nations. Women ages 40 - 44 years are almost certain than all other age gatherings to utilize female sterilization, with 51 percent picking it as their essential birth control strategy [8]. For women, evidence recommends that tubal ligation has non-preventative advantages, for example, diminishing the danger of malignant ovarian growth [9]. Permanent contraception incorporates vasectomy for men 
and tubal procedure for women, which are very successful, with disappointment rates of short of what one percent [10]. Finally, research about tubal ligation shown the method is safer, with a low rate of complications or then again disappointment when performed by standard practice [11]. The constant utilization of LAPMs is, to a great extent, dictated by the level of education and income level and the quantity of surviving kids. Reproductive of wellbeing health programs can consider this gathering of women for mediations going for improving the fertility rate [12].

Poor and underestimated women typically have high neglected requirements for modern contraception particularly separating techniques, and therefore, they become helpless against encountering poor conceptive results including high rates of unintended and undesirable pregnancies [13]. Ethnic status is one more wellspring of segregation for poor women from planned clans, booked positions, and others in reverse communities [14]. The probability of sterilization expanded with lower financial status in Bangladesh and India, while higher financial status was related with a greater likelihood of sterilization used in Latin America and the Caribbean.

Resistance to the utilization of sterilization likewise has been noted among Muslim groups in India and the Philippines [15] [16]. Different countries have taken different attempting where sterilization predominance is low, especially those countries situated in the Middle East, in North Africa, and Sub-Saharan Africa. The low use in these nations might be a part of sterilization strategies dependent on the strict application of religion or individual position to sterilization. A few investigations demonstrated that women with advanced education, the age of the woman and socioeconomic status have critical impact concerning contraceptive strategies of adoption decision [17] [18]. A higher number of living children has motivated the couples to take a contraceptive method [19]. Moreover, higher parity couples have intentions to use permanent contraceptive methods in Asia and Latin America who have average 4 - 5 children [20].

Previous studies found that contraceptive method, especially sterilization method choice depends on different demographic and socioeconomic characteristics of the respondents. Few studies demonstrated the regional variation, and urban-rural differentials affect the sterilization method choice. This paper aims to bridge the gap between the sterilization method choice and regional variation.

\section{Materials and Methods}

This study uses data extracted from the 2014 Bangladesh Demographic and Health Survey (BDHS 2014). The principal interest of the study is the use of a permanent contraceptive method. Moreover, the study employed several independent variables which are Respondent's education, Respondent's working status, Husband's Education, Husband's occupation, Pace of Residence, Religion, Age at first marriage, Access to Mass Media, Region, Socioeconomic Condition, Continues study after marriage, Number of living son(s).

The education of the respondents and their partners (no education, primary, 
secondary, and higher education) may be an essential determinant to be sterilized. Socioeconomic measures included the working status of the respondent which categorized as working at the time of the survey or not; religion of the respondent recoded as Muslim and Non-Muslim; partner's occupation classified as agriculture, service, business, and other; and socioeconomic status grouped as poor, middle, and rich. Other measures in the analysis were the place of residence which is classified as urban and rural; age at first marriage, which is recoded by considering median age. A media exposure index indicated whether the respondent used TV, radio or print media (categorized as "0" if they never used any of the media, and " 1 " if they indicated they used at least one of the media sources).

The relationship between choice of sterilization method and different independent variables in this study were tested by applying cross-tabulation, which is the first step to identify those explanatory variables responsible for method choice of sterilization. But cross-tabulation fails to explain the changes in each of the predictor categorical variables. These changes of predictor variables were measured by applying multivariate logistic regression analysis.

\section{Trends of Sterilization}

Couples regularly settle on sterilization commonly, when the two of them feel they don't need any more kids. If a couple decides on sterilization as their favored preventative strategy, either partner could be sterilized. Since these techniques can't be fixed, they are prescribed for women who are certain that they would prefer not to have any child later on. Table 1 shows the percentage of sterilized women in the last decade in Bangladesh. In Bangladesh, 6.2 percent of married women had been sterilized in the year 2011, followed by the year 2004 (5.61\%). The acknowledgment of sterilization begun to increment gradually, however, this pattern was not kept up, and the year 2014 saw reliably low degrees of sterilization acceptors (5.25\%). The percentage of sterilized of married women in 2014 had been decreased by 0.95 with compare to the year 2011 .

The trend line shows that the sterilization rate had 0.004 point decrease in the last decade in Bangladesh. This reduction of taking permanent method due to frightened of a health problem or religious concept. Moreover, the reduction of the permanent method is probably the unavailability or utilization of family planning services (Figure 1).

\section{Results and Discussion}

The quick development in Bangladesh's population can, to a great extent, be ascribed to the age distribution of its population. While sterilization appears a viable answer for the issue of overpopulation in a developing country, education and proficiency could engage women to settle on capable safeguard choices. This information could then go down from age to age, making an enduring impact on the people. Table 2 shows that higher educated women were less likely to be sterilized than the illiterate woman. In our study, 16.3 percent of illiterate women 
were sterilized, whereas only 2.7 percent of higher educated respondents were sterilized. In many North African and South Asian countries, the majority of sterilized women have no formal education [20].

Moreover, in many South Asian countries, illiterate women have a strong desire for large family size and especially have the desire for sons [21] [22]. The reason for sterilization among illiterate women may be attributed that they achieved the desired family size. Working women in Bangladesh were more conscious regarding sterilization than nonworking women. The study found that 10.8 percent of working women were used a permanent contraceptive method, whereas only 8.6 percent of nonworking women were sterilized. Husband education had the same scenario like as women education. The occupation of husband indicates that agriculturist husbands were more likely to use a permanent contraceptive method than service hold or business occupation husband. The reason may be attributed to the communication of family planning field worker and also the desired number of children achieved by agriculture worker. The place of residence also supports this pattern. In Bangladesh, the majority of rural people depend on agriculture, and the result of Table 2 shows that rural respondents were more likely to use a permanent contraceptive method than urban respondents.

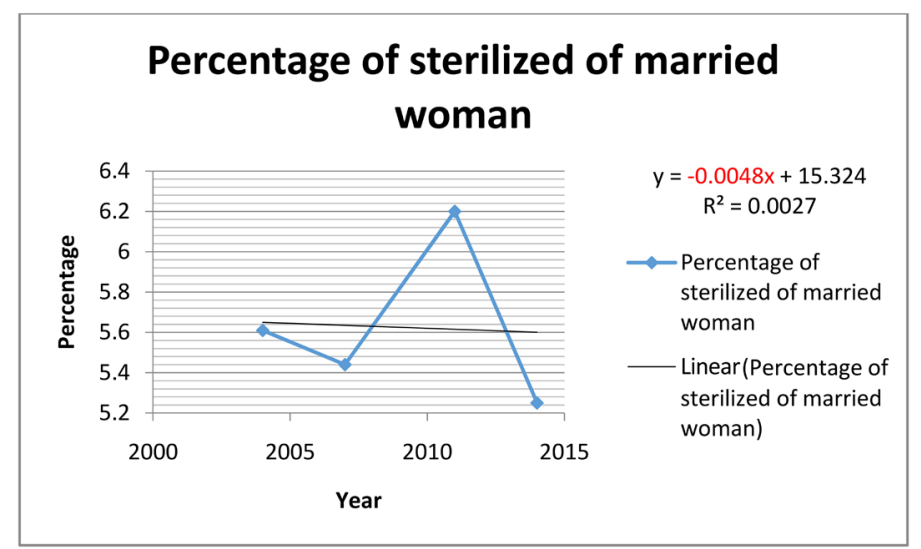

Figure 1. Trends of sterilized women in Bangladesh, 2004-2014.

Table 1. Number of married women, number of contraceptive user and percentage of sterilized women in Bangladesh.

\begin{tabular}{ccccc}
\hline Year & $\begin{array}{c}\text { Number of a } \\
\text { married woman } \\
\text { included in the } \\
\text { survey }\end{array}$ & $\begin{array}{c}\text { Number of a } \\
\text { woman using } \\
\text { any contraceptive } \\
\text { method during the } \\
\text { survey time }\end{array}$ & $\begin{array}{c}\text { Number of } \\
\text { sterilized woman }\end{array}$ & $\begin{array}{c}\text { Percentage of } \\
\text { sterilized of the } \\
\text { married woman }\end{array}$ \\
\hline 2004 & 11440 & 6157 & 642 & 5.61 \\
2007 & 10996 & 5628 & 598 & 5.44 \\
2011 & 16635 & 10183 & 1032 & 6.20 \\
2014 & 16858 & 10528 & 885 & 5.25 \\
\hline
\end{tabular}

Source: Author's elaboration using BDHS 2004, 2007, 2011, 2014 survey dataset. 
Table 2. Percentage of married women who had been sterilized in Bangladesh.

\begin{tabular}{|c|c|c|}
\hline Background Characteristics & $\begin{array}{l}\text { Number of respondents and } \\
\text { Percentage of the respondents } \\
\text { who had been sterilized }\end{array}$ & $\begin{array}{l}\text { Values of } \\
\text { Chi-square }\end{array}$ \\
\hline \multicolumn{3}{|l|}{ Respondent's education } \\
\hline Illiterate & $396(16.3)$ & \multirow{4}{*}{$251.798^{* * *}$} \\
\hline Primary & $328(10.6)$ & \\
\hline Secondary & $236(5.9)$ & \\
\hline Higher & $26(2.7)$ & \\
\hline \multicolumn{3}{|l|}{ Respondent Currently Working } \\
\hline No & $591(8.6)$ & \multirow{2}{*}{$13.557^{\star * *}$} \\
\hline Yes & $395(10.8)$ & \\
\hline \multicolumn{3}{|l|}{ Husband's Education } \\
\hline Illiterate & $424(14.3)$ & \multirow{4}{*}{$168.422^{* * *}$} \\
\hline Primary & $283(9.6)$ & \\
\hline Secondary & $228(7.4)$ & \\
\hline Higher & $50(3.2)$ & \\
\hline \multicolumn{3}{|l|}{ Husband's Occupation } \\
\hline Agriculture & $289(10.6)$ & \multirow{4}{*}{$45.02^{* * *}$} \\
\hline Service & $278(10.1)$ & \\
\hline Business & $368(7.7)$ & \\
\hline Others & $51(17.6)$ & \\
\hline \multicolumn{3}{|l|}{ Type of Place of Residence } \\
\hline Urban & $275(8.9)$ & \multirow{2}{*}{1.297} \\
\hline Rural & $711(9.6)$ & \\
\hline \multicolumn{3}{|l|}{ Religion } \\
\hline Muslim & $852(9.1)$ & \multirow{2}{*}{$7.34^{* * *}$} \\
\hline Non-Muslim & $134(11.6)$ & \\
\hline \multicolumn{3}{|l|}{ Age at First Marriage } \\
\hline$\leq 15$ years & $635(11.6)$ & \multirow{2}{*}{$66.584^{\star * *}$} \\
\hline$>15$ years & $351(7.0)$ & \\
\hline \multicolumn{3}{|l|}{ Access to Mass Media } \\
\hline No Access & $421(11.1)$ & \multirow{2}{*}{$21.290^{* * *}$} \\
\hline Have Access & $565(8.4)$ & \\
\hline \multicolumn{3}{|l|}{ Region } \\
\hline Barisal & $39(5.9)$ & \multirow{4}{*}{$68.095^{\star * *}$} \\
\hline Chittagong & $134(7.8)$ & \\
\hline Dhaka & $300(8.1)$ & \\
\hline Khulna & $121(10.4)$ & \\
\hline
\end{tabular}




\section{Continued}

\begin{tabular}{cc} 
Rajshahi & $138(9.9)$ \\
Rangpur & $163(12.0)$ \\
Sylhet & $91(16.6)$ \\
Socio-economic Condition & \\
Poor & $440(11.1)$ \\
Middle & $200(9.4)$ \\
Rich & $345(7.8)$ \\
No & \\
Yes & $960(9.9)$ \\
Number of living son(s) & $26(3.1)$ \\
No sons & \\
One son & $78(3.3)$ \\
Two sons & $362(7.8)$ \\
Three sons & $377(14.7)$ \\
Four or more sons & $124(18.0)$ \\
Overall & $45(18.3)$ \\
& $986(9.4)$ \\
\hline
\end{tabular}

Source: Author's elaboration using BDHS 2014 survey dataset; Note: ${ }^{*} \mathrm{p}<0.10,{ }^{* *} \mathrm{p}<0.05 ;{ }^{* * *} \mathrm{p}<0.01$.

Religious expression and values continue to influence the contraceptive method use. Non-Muslim respondents were 2.5 percent more sterilized than their Muslim counterparts. The demographical variable age at first marriage indicates that respondents who married before age 15 years were more tendency to be sterilized than those married after age 15 years. The probable reason for being sterilized is that they achieved the desired number of children. Occupations, rural area, age at first marriage and access to mass media have an association in Bangladesh. Mass media has a limited reach to the rural population in developing countries [23]. It is found that 11.1 percent of women who never access in mass media were sterilized, whereas only 8.4 percent women at least access in any mass media did the same.

It is pointed out that there are significant inconsistencies in the accessibility and nature of family planning and health services benefit in the different region of developing nation [24]. In terms of regional patterns, a higher sterilization rate is observed in Sylhet (16.6\%) followed by Rangpur (12.0\%) and Khulna (10.4\%). The lowest figure is found in Barisal (5.9\%) division. The cultural and social status affects the use of an irreversible method of family planning. In the time of the survey, 11.1 percent of married women who belong to lower stratum used irreversible family planning method, which figure is only 7.8 percent at the upper stratum class. The most interesting point in this study is found that women who continue their study after marriage were only 3.1 percent of them 
being sterilized, whereas 9.9 percent those did not continue their education used a permanent contraceptive method. In a study, Melka et al. [25] found that women with more than two children were more likely to use irreversible contraceptive method than those had at most two living children. This study also found that gender preference is an important factor to decide sterilization. Women with four or more sons were more likely being sterilized than women with no sons and one son.

Table 3 indicates the multivariate logistic regression analysis, where we consider those variables found significant in bivariate analysis. It is found that women at least literate were less likely to use irreversible contraceptive method than those women who had no education. Higher educated women were 57.8 percent decrease in the odds being sterilized than illiterate women. The positive expectation of women may be associated with sterilization because sterilized women might think that their social life will be improved by facilitating education development [26]. Women working status play a significant role on permanent contraceptive use. The study identified that working women were 1.135 times more likely to utilize a permanent contraceptive method than non-working women. Husband education indicates similar findings with women education.

Table 3. Estimated odds ratio from binary logistic regression models between selected measures and use of sterilization method.

\begin{tabular}{|c|c|c|c|}
\hline Background Characteristics & $\begin{array}{l}\text { Logistic regression } \\
\text { co-efficient }(\beta)\end{array}$ & Standard Error & Odds Ratio $[\operatorname{Exp}(\beta)]$ \\
\hline \multicolumn{4}{|l|}{ Respondent's education } \\
\hline Illiterate (RC) & -- & -- & 1.00 \\
\hline Primary & -0.373 & 0.086 & $0.689^{* * *}$ \\
\hline Secondary & -0.863 & 0.105 & $0.422^{* * *}$ \\
\hline Higher & -1.115 & 0.260 & $0.328^{* * *}$ \\
\hline \multicolumn{4}{|l|}{$\begin{array}{c}\text { Respondent Currently } \\
\text { Working }\end{array}$} \\
\hline No (RC) & -- & -- & 1.00 \\
\hline Yes & 0.127 & 0.072 & $1.135^{\star}$ \\
\hline \multicolumn{4}{|l|}{ Husband's Education } \\
\hline Illiterate (RC) & -- & -- & 1.00 \\
\hline Primary & -0.244 & 0.088 & $0.783^{* * *}$ \\
\hline Secondary & -0.360 & 0.103 & $0.698^{\star * *}$ \\
\hline Higher & -0.842 & 0.189 & $0.431^{* * *}$ \\
\hline \multicolumn{4}{|l|}{ Husband's Occupation } \\
\hline Agriculture (RC) & -- & -- & 1.00 \\
\hline Service & 0.209 & 0.094 & $1.232^{* *}$ \\
\hline
\end{tabular}




\section{Continued}

\begin{tabular}{|c|c|c|c|}
\hline Business & -0.101 & 0.088 & 0.904 \\
\hline Others & 0.858 & 0.178 & $2.358^{\star * *}$ \\
\hline \multicolumn{4}{|l|}{ Religion } \\
\hline Muslim (RC) & -- & -- & 1.00 \\
\hline Non-Muslim & 0.315 & 0.104 & $1.370^{* * *}$ \\
\hline \multicolumn{4}{|l|}{$\begin{array}{c}\text { Age at } \\
\text { First Marriage }\end{array}$} \\
\hline$\leq 15$ years $(\mathrm{RC})$ & -- & -- & 1.00 \\
\hline$>15$ years & -0.287 & 0.076 & $0.750^{* * *}$ \\
\hline \multicolumn{3}{|l|}{ Access to } & Mass Media \\
\hline No Access & -- & -- & 1.00 \\
\hline Have Access & 0.077 & 0.085 & 1.080 \\
\hline \multicolumn{4}{|l|}{ Region } \\
\hline Barisal (RC) & -- & -- & 1.00 \\
\hline Chittagong & 0.224 & 0.191 & 1.251 \\
\hline Dhaka & 0.187 & 0.180 & 1.206 \\
\hline Khulna & 0.538 & 0.194 & $1.713^{* * *}$ \\
\hline Rajshahi & 0.426 & 0.192 & $1.531^{\star *}$ \\
\hline Rangpur & 0.650 & 0.188 & $1.916^{* * *}$ \\
\hline Sylhet & 0.961 & 0.205 & $2.613^{\star * *}$ \\
\hline \multicolumn{4}{|l|}{ Socio-economic } \\
\hline \multicolumn{4}{|l|}{ Condition } \\
\hline Poor (RC) & -- & -- & 1.00 \\
\hline Middle & 0.097 & 0.099 & 1.101 \\
\hline Rich & 0.252 & 0.102 & $1.286^{* *}$ \\
\hline \multicolumn{4}{|l|}{$\begin{array}{c}\text { Continues study after } \\
\text { marriage }\end{array}$} \\
\hline No (RC) & -- & -- & 1.00 \\
\hline Yes & -0.457 & 0.230 & $0.633^{* *}$ \\
\hline \multicolumn{4}{|l|}{$\begin{array}{l}\text { Number of } \\
\text { living son(s) }\end{array}$} \\
\hline No son (RC) & -- & -- & 1.00 \\
\hline One son & 0.925 & 0.128 & $2.522^{* * *}$ \\
\hline Two sons & 1.636 & 0.128 & $5.134^{\star * *}$ \\
\hline Three sons & 1.880 & 0.152 & $6.555^{\star * *}$ \\
\hline Four or more sons & 1.899 & 0.201 & $6.682^{* * *}$ \\
\hline Constant & -2.092 & 0.189 & $0.123^{* * *}$ \\
\hline
\end{tabular}

Source: Author's elaboration using BDHS 2014 survey dataset; Note: ${ }^{*} \mathrm{p}<0.10,{ }^{* *} \mathrm{p}<0.05{ }^{* * *} \mathrm{p}<0.01$. 
Women whose husbands were service holder were 1.232 times more likely to use irreversible contraceptive method than women whose husbands were agriculturists. On the other hand, husbands who were day labor or religious employed (called Imam) namely in others category were 2.358 times more likely to utilize permanent contraceptive method than Women whose husbands were daily laborers were 4.4 times more likely to use LAPMs as compared with women whose husbands were government employees husband. This finding is steady with the reports of certain nations where the chances of favoring family arranging are higher at the point when the husband is employed [27] [28].

Religious followers generally shift in their perspectives on conception prevention. This can be genuine even between various parts of one confidence, as on account of religion. Some religious devotees find that their own feelings of the utilization of anti-conception medication vary from the convictions embraced by the leaders of their faith. It is found that Non-Muslim women in Bangladesh were 1.37 times more likely to be permanent contraceptive user than Muslim women. Reproductive age of the respondents is important factors to determine the use of the irreversible contraceptive method. Women who married before the age 15 years were 25.0 percent decrease in odds to use permanent family planning method than those married age 15 years of age.

However, disparities in the use of a permanent contraceptive method were evident by regions, wealth index, and women educational status after marriage [29]. The study also found the regional variation in the use of the irreversible contraceptive method. In Sylhet, respondents were two and half times more likely to use permanent family planning method than respondents from Barisal region in Bangladesh. Furthermore, the socioeconomic status indicates that respondents from upper quartile were 1.286 times more likely to use irreversible method than respondents from lower quartile. Besides, respondents who continued their study after marriage were 36.7 percent decrease in odds to take a permanent contraceptive method than those who did not continue their study.

Women with a few children favor a permanent contraceptive strategy, and those with fewer children incline toward permanent contraceptive techniques. Likewise, older married women lean toward irreversible contraceptive method while more young ladies favor short time contraceptive techniques [30]. Women who accept that they have adequate quantities of kids usually want to space the birth of the next child or need as far as possible to utilize permanent contraceptive method rather than preventative strategies at short term. The study found that women at least three sons were six and half times more to use permanent contraceptive methods than those who have no sons. This result is supported by many of the researchers worldwide [31] [32] [33]. Moreover, when couples do not have any sons but have a daughter, they usually like to use a modern or traditional contraceptive method to give space between two births [34].

\section{Conclusion}

Although success in family planning program is widely acclaimed in Bangladesh, 
there are many challenges to achieve the desired growth in case of permanent contraceptive use. Based on the findings of the study it is concluded that women working status, socioeconomic condition, area of resident, religion and number of living children were significantly associated with the adoption of irreversible contraceptive method. The decision-maker should create a comfortable level of working place for women, which will directly improve their social status. This strategy may influence the women for uptake of the permanent contraceptive method choice irrespective of the number of living children. Also, efforts need to be aimed at women empowerment and treat equally male child and female child in society. Moreover, consciousness needs to create to marry at legal age. Beside husbands should be discussed with their spouses on permanent contraceptive use technique take-up, and birth arranging as they play a real job in choices to restrict/space childbirth. The concerned authority with religious leader should continue the promotional activities regarding the intake of permanent contraceptive method and need to make a campaign to reduce the fear of side effect of the above-mentioned method. However, there is unavailability of the data of the number of abortion occurring in a woman life that may be influenced on the decision of sterilization and this deficiency in this study should be addressed in future research.

\section{Conflicts of Interest}

The authors declare no conflicts of interest regarding the publication of this paper.

\section{References}

[1] Moreland, S., Smith, E. and Sharma, S. (2010) World Population Prospects and Unmet Need for Family Planning. Futures Group, Washington DC.

[2] Ashford, L. (2003) Unmet Need for Family Planning: Recent Trends and Their Implications for Programs. Measure Communication Policy Brief, PRB.

[3] Eeckhaut, M.C., Sweeney, M.M. and Gipson, J.D. (2014) Who Is Using Long-Acting Reversible Contraceptive Methods? Findings from Nine Low Fertility Countries. Perspectives on Sexual and Reproductive Health, 46, 149-155. https://doi.org/10.1363/46e1914

[4] Banerjee, B. (2004) Socio-Economic and Cultural Determinants of Acceptance of Permanent Methods of Contraception. The Journal of Family Welfare, 50, 54-578.

[5] Mannan, H.R. (2002) Factors in Contraceptive Method Choice in Bangladesh: Goals, Competence, Evaluation and Access. Contraception, 65, 357-364. https://doi.org/10.1016/S0010-7824(01)00303-1

[6] Hogan, D.P., Berhanu, B. and Hailemariam, A. (1999) Household Organization, Women's Autonomy, and Contraceptive Behavior in Southern Ethiopia. Studies in Family Planning, 30, 302-314. https://doi.org/10.1111/j.1728-4465.1999.t01-2-.x

[7] Khan, M.A. and Rahman, M. (1997) Determinants of Contraceptive Method Choice in Rural Bangladesh. Asia Pacific Journal, 12, 65-82. https://doi.org/10.18356/54feccff-en

[8] Jones, J., Mosher, W. and Daniels, K. (2012) Current Contraceptive Use in the 
United States, 2006-2010, and Changes in Patterns of Use since 1995. National Health Statistics Reports No. 60. National Center for Health Statistics, Hyattsville.

[9] Cibula, D., Widschwendter, M., Majek, O. and Dusek, L. (2011) Tubal Ligation and the Risk of Ovarian Cancer: Review and Meta-Analysis. Human Reproduction Update, 17, 55-67. https://doi.org/10.1093/humupd/dmq030

[10] Trussell, J. (2011) Contraceptive Failure in the United States. Contraception, 83, 397-404. https://doi.org/10.1016/j.contraception.2011.01.021

[11] Ruminjo, J.K. and Lynam, P.F. (1997) A Fifteen-Year Review of Female Sterilization Byminilaparotomy under Local Anesthesia in Kenya. Contraception, 55, 249-260. https://doi.org/10.1016/S0010-7824(97)00004-8

[12] Azmoude, E., Behnam, H., Barati-Far, S. and Aradmehr, M. (2017) Factors Affecting the Use of Long-Acting and Permanent Contraceptive Methods among Married Women of Reproductive Age in East of Iran. Women's Health Bulletin, 4, e44426. https://doi.org/10.5812/whb.44426

[13] Raj, A., Saggurti, N., Balaiah, D. and Silverman, J.G. (2009) Prevalence of Child Marriage and Its Impact on the Fertility and Fertility Control Behaviors of Young Women in India. The Lancet, 373, 1883-1889. https://doi.org/10.1016/S0140-6736(09)60246-4

[14] Baru, R., Acharya, A., Acharya, S., Kumar, A.K.S. and Nagaraj, K. (2010) Inequities in Access to Health Services in India: Caste, Class and Region. Economic and Political Weekly, 45, 49-58.

[15] Population Council (1993) Introduction of an IEC Package for Rural Women of Maguindanao. Commission on Population, Population Council, Manila.

[16] Khan, M.E. and Patel, B.C. (1997) Reproductive Behaviour among Muslims in Uttar Pradesh. Population Council, Asia and Near East Operations Research and Technical Assistance Project, New Delhi.

[17] Erlenwein, J., Kundu, S., Schippert, C., Soergel, P., Hillemanns, P. and Staboulidou, I. (2015) Attitude toward, Acceptance of and Knowledge about Female Sterilization as a Method of Contraception. European Journal of Obstetrics \& Gynecology and Reproductive Biology, 185, 83-87. https://doi.org/10.1016/j.ejogrb.2014.11.028

[18] Ogedengbe, O.K., Giwa-osagie, O.F. and Usifoh, C.A. (1990) The Attitude of Fertile Nigerian Women to Sterilization. Biology and Society, 7, 135-138.

[19] Hoq, M.N. (2016) Factors Affecting on Current Contraception Use among Currently Married Women in Urban and Rural Areas of Bangladesh. IOSR Journal of Humanities and Social Science, 21, 22-30.

[20] Engender Health (2002) Factors Influencing Sterilization Use and Outcomes. In: Contraceptive Sterilization: Global Issues and Trends, Engender Health, New York, Chapter 5, 107-137.

https://www.engenderhealth.org/wp-content/uploads/imports/files/pubs/family-pla nning/factbook_chapter_5.pdf

[21] Akmam, W. (2002) Women's Education and Fertility Rates in Developing Countries, with Special Reference to Bangladesh. Eubios Journal of Asian and International Bioethics, 12, 138-143.

[22] Hoq, M.N. (2019) Effects of Son Preference on Contraceptive Use in Bangladesh. Kesmas: National Public Health Journal, 14. https://doi.org/10.21109/kesmas.v14i1.2848

[23] Ganju, D., Bhatnagar, I., Hazra, A., Jain, S. and Khan, M.E. (2010) Reach of Media and Interpersonal Communication in Rural Uttar Pradesh. The Journal of Family 
Welfare, 56, 83-91.

[24] Leite, I.C. and Gupta, N. (2007) Assessing Regional Differences in Contraceptive Discontinuation, Failure and Switching in Brazil. Reproductive Health, 4, 6. https://doi.org/10.1186/1742-4755-4-6

[25] Melka, A.S., Tekelab, T. and Wirtu, D. (2015) Determinants of Long Acting and Permanent Contraceptive Methods Utilization among Married Women of Reproductive Age Groups in Western Ethiopia: A Cross-Sectional Study. The Pan African Medical Journal, 21, 246. https://doi.org/10.11604/pamj.2015.21.246.5835

[26] Cushman, L.F., Philliber, S.G., Davidson, A.R., Graves, W.L. and Rulin, M.C. (1988) Beliefs about Contraceptive Sterilization among Low-Income Urban Women. Family Planning Perspectives, 20, 218-233. https://doi.org/10.2307/2135623

[27] Haile, A. and Fantahun, M. (2012) Demand for Long Acting and Permanent Contraceptive Methods and Associated Factors among Family Planning Service Users, Batu Town, Central Ethiopia. Ethiopian Medical Journal, 50, 31-42.

[28] Mekonnen, F.A., Mekonnen, W.N. and Beshah, S.H. (2017) Predictors of Long Acting and Permanent Contraceptive Methods Utilization among Women in Rural North Shoa, Ethiopia. Contraception and Reproductive Medicine, 2, 22. https://doi.org/10.1186/s40834-017-0049-2

[29] Wado, Y.D., Gurmu, E., Tilahun, T. and Bangha, M. (2019) Contextual Influences on the Choice of Long-Acting Reversible and Permanent Contraception in Ethiopia: A Multilevel Analysis. PLoS ONE, 14, e0209602. https://doi.org/10.1371/journal.pone.0209602

[30] Khan, M.A. (1996) Factors Affecting Use of Contraception in Matlab, Bangladesh. Journal of Biosocial Science, 28, 265-279. https://doi.org/10.1017/S0021932000022343

[31] Agha, S. (2010) Intentions to Use Contraceptives in Pakistan: Implications for Behavior Change Campaigns. BMC Public Health, 10, 450.

https://doi.org/10.1186/1471-2458-10-450

[32] Earsido, A., Gebeyehu, A. and Kisi, T. (2015) Determinants of Long-Acting and Permanent Contraceptive Methods Utilization among Married Women in Hossana Town, Southern Ethiopia: A Case-Control Study. Journal of Pregnancy and Child Health, 2, 165. https://doi.org/10.4172/2376-127X.1000165

[33] Bulto, G.A., Zewdie, T.A. and Beyen, T.K. (2014) Demand for Long Acting and Permanent Contraceptive Methods and Associated Factors among Married Women of Reproductive Age Group in DebreMarkos Town, Northwest Ethiopia. BMC Women's Health, 14, 46. https://doi.org/10.1186/1472-6874-14-46

[34] De Oliveira, I.T., Dias, J.G. and Padmadas, S.S. (2014) Dominance of Sterilization and Alternative Choices of Contraception in India: An Appraisal of the Socioeconomic Impact. PLOS ONE, 9, e86654. https://doi.org/10.1371/journal.pone.0086654 